\title{
The Impact of the 2008 German Corporate Tax Reform: A dynamic CGE Analysis*
}

\author{
Doina Radulescu \\ Center for Economic Studies, \\ University of Munich and CESifo ${ }^{\dagger}$
}

\author{
Michael Stimmelmayr \\ Center for Economic Studies, \\ University of Munich and CESifo ${ }^{\ddagger}$
}

This version: January 2009

\begin{abstract}
In this paper we develop the dynamic CGE model, ifoMod, which is designed to analyse the impact of fundamental tax reforms and in particular capital income tax reforms for Germany. The model is in line with neoclassical growth theory and features all important behavioural interactions between the four major building blocks of an economy including the firm and household sector, the government and the rest of the world. We consider firms of different legal forms which all face an inter-temporal investment problem, a financing problem w.r.t. the optimal choice of debt and equity financing as well as the factor input problem when deciding on the optimal amount of different skill types of labour employed. We show the impact of different types of taxes on the behavioral margins of firms and households and the conducted simulation shows the impact of the latest German corporate tax reform of 2008 on the German macroeconomic variables such as investments, GDP, consumption and household's welfare.
\end{abstract}

Keywords: Capital income taxation, computable general equilibrium modeling, welfare analysis.

JEL-Classification: C68, D58, D92, E62, H25

\footnotetext{
*The authors would like to thank Christian Keuschnigg for his valuable support. His comments and continuous motivation were especially helpful during the research stays at the University of St.Gallen

$\dagger^{\dagger}$ ESS, University of Munich, Schackstr. 4, 80539 Munich, Germany, Radulescu@lmu.de

${ }^{\ddagger}$ CES, University of Munich, Schackstr. 4, 80539 Munich, Germany, Stimmelmayr@lmu.de
} 


\section{Introduction}

The effects of a comprehensive tax reform are manifold. Beside the more obvious first order effects economy-wide repercussions and second-order effects have to be considered, too, such that it has become a difficult task to evaluate and quantify the impact of comprehensive tax reforms. In this regard, Computable General Equilibrium (CGE) models have proved to be a straightforward instrument to asses the quantitative impact and relative efficiency of alternative tax instruments as well as the distributional, fiscal and allocative effects of various tax reform proposals.

Computable General Equilibrium (CGE) models are these days widely applied in various fields of economics and policy advice. The theoretical underpinning of CGE modelling has its seed in the Walrasian equilibrium (WALRAS 1877) theory as well as the modern conception of the general equilibrium theory à la ARROW and DEBREU (1954). The first numerical approaches in solving Arrow-Debreu general equilibrium system were pioneered by Scarf (1967) and his scholars Shoven and Whalley $(1972,1973)$ in the 1970's. The more recent CGE models have, however, advanced remarkably since then. Nowadays CGE models are marked by a high degree of complexity with regard to both the specification of the behavioural features of economic agents as well as sector and factor market linkages. These complex systems of quantitative linkages enable us to analyse not just the qualitative but also quantitative implications of comprehensive policy reforms. In detail, CGE models are built to shed light on the short and long term repercussions of issues such as international trade agreements, like the Doha Trade Round, environmental issues such as climatic changes and the impact of pollution permits, scenarios of imperfect competition or public finance issues, i.e. pension funding in ageing societies or comprehensive tax reforms with dynamic features. ${ }^{1}$

In this paper we develop the dynamic CGE model, ifoMod, which is designed to analyse the impact of fundamental tax reforms and in particular capital income tax reforms for Germany. Our model is in line with neoclassical growth theory and features all important

\footnotetext{
${ }^{1}$ One drawback of CGE models refer to their strict dependence on the functional forms considered and parameter values applied. These kind of critique, however, applies to other forms of economic tools, as well and in particular to econometric models (Fossati and Wiegard, 2002).
} 
behavioural interactions between the four major building blocks of an economy including the firm and household sector, the government and the rest of the world. In detail, we consider firms of two different legal forms, e.g. corporate an non-corporate firms which differ with regard to their tax treatment. Both types of firms face an inter-temporal investment problem, a financing decision problem w.r.t. the optimal choice of debt and equity financing as well as the factor input problem when deciding on the optimal amount of different skill types of labour employed. The marginal investment is assumed to be partly debt and partly equity financed via new share issues and retained earnings, such that our model combines the 'Old View' and 'New View' of dividend taxation - even though the model is strongly biased towards the 'New View'.2 This is the case, since the lion's share of investment funds stems from retained earnings.

On the household side, we apply the traditional Ramsey model (RAMSEY 1928) which, due to its dynastic linkage between generations, enables us to conduct a coherent welfare analysis for any kind of reform. ${ }^{3}$ Our representative agent is endowed with three different skill types of labour and maximizes her life-time utility by choosing the optimal intertemporal pattern of consumption and optimal labour supply of each skill type. In addition, the agent has to solve a portfolio choice problem, since ifoMod features four different types of assets, encompassing firm equity, firm bonds as well as domestic and foreign government bonds.

The government introduces various distortions on the behavioural margins of agents through taxation. In total, we consider seven different types of taxes, including a corporate tax, a tax on profits of non-corporate firms (which is identical to the personal income tax of the firm proprietor), a tax on labour income as well as personal taxes on capital income such as interest income, dividends and capital gains (thereby the taxation of the financial assets follows the residence principle of taxation). Finally, we also consider a value added

\footnotetext{
${ }^{2} \mathrm{~A}$ focal issue in the literature is whether investments are financed by new equity issues or retrained earnings at the margin. The former is referred to as the Old View of dividend taxation, while the latter is referred to as the New View of dividend taxation. The New View was first published by King (1974, 1977), Auerbach (1979) and Bradford (1981). See e.g. Sinn (1991a) for an illustration of the two views.

${ }^{3}$ Contrary to that, in an overlapping generations (OLG) framework which is also frequently applied in CGE modelling, new generations virtually 'drop from heaven' and it is unclear how to account for their welfare gain or loss resulting from policy reforms.
} 
$\operatorname{tax}(\mathrm{VAT})$. The governments's actions are restricted by the European Stability and Growth Pact which limits the government's budget deficit to three percent of GDP and the level of government debt to 60 percent of GDP. Last but not least, the Rest of the World (RoW) is modelled as a foreign economy which is about ten times larger than the home economy. Therefore, our framework can be regarded as a two country setting with little influential power of the home country. The foreign economy is, however, only roughly modeled and serves merely to complete the general equilibrium framework.

Altogether, the model mimics every important behavioural margin at the firm and household level that is strongly sensitive to the effects of capital income taxation. Furthermore, the model does not only compute the economy's new steady state solution under the new tax rules as it is the case in any static analysis. Since our model is a fully dynamic, micro based macro model it additionally accounts for the behavioural reactions of agents and features the whole path of equilibria from the initial to the final steady state equilibrium. This is in particular important for the savings and investment decisions which are by nature forward looking and thus are marked by important tax capitalization effects. For example, each single change in any capital income tax triggers an adjustment in the firm's financial behavior, like a reshuffle of the firm's source of finance and use of funds, which in turn influences the resulting cost of capital and therewith the firm's investment decision and its accumulation of capital. The capital intensities of each representative firm affect the demand for the different skill types of labour and thus have a major repercussion on the household income and consumption profile. In addition, our model offers information on the marginal excess burden of each particular tax considered and the conducted welfare analysis is based on the equivalent variation in consumption. ${ }^{4}$

ifoMod was appreciated by the German Council of Economic Advisors (GCEA, 2005) as being a state-of-the-art model and one of the most developed and advanced CGE models of the type which can be used to simulate capital income tax reforms for Germany. It was also applied to quantify the complex effects of introducing a Dual Income Tax in Germany for the GCEA (2006). It has a sound theoretical foundation such that one can also draw on the underlying core economic model to explain the simulation results.

\footnotetext{
${ }^{4}$ A detailed discussion of the model is found in Readulescu (2007) or Stimmelmayr (2007).
} 
Among comparable CGE models which are predominantly dedicated to tax analyses in European economies we can count the model by Fehr (1999), KeuschnigG (2004) and Dietz and Keuschnigg (2003, 2004 and 2007) and SøRensen (2001) for example.

The model by FEHR (1999) uses a dynamic simulation model of the AUERBACHKotlikoff (1987) type featuring intragenerational heterogeneity. The focus of this model is on distributional and efficiency aspects of different fical reform packages including proposals to reform the German pension system.

The IFF Tax Model is another important CGE model developed by KeuschnigG (2004) and Dietz and Kesuchnigg (2003, 2004, and 2007). This model is also a fully dynamic model and was built to evaluate fundamental tax reforms for the Swiss economy. It encompasses features like firms of different legal status, an endogenous dividend and debt policy as well as in- and outward FDI by multinationals. On the OLG household side endogenous labour supply and international portfolio investments with home bias are considered.

Finally, OECDTAX, developed by SøREnsen (2001), is intended to describe the international cross-border effects resulting from national tax policies via the world capital market as well as international tax coordination within the OECD countries. Therefore, the model considers a detailed private portfolio composition, foreign direct and foreign portfolio investments, a housing market, endogenous corporate financial policies as well as a labour market with structural unemployment. This richness of details, implies however, that one has to cut back somewhere else on the modelling side, such that OECDTAX is static describing only a stationary long-run equilibrium.

The present paper is structured as follows: the first part introduces the model with a detailed description of its four building blocks. Within this section, special attention is paid to the financing and investment decision of the different firm types. The second part presents the simulation analysis conducted which focuses on the latest German corporate tax reform which became effective as of the $1^{\text {st }}$ of January 2008. 


\section{The Model}

\subsection{Production \& Investments}

The most important building block of our model is the intertemporal investment model with convex adjustment costs in the spirit of ToBIN's (1969) Q-Theory of investments.

Both the corporate and the non-corporate sector draw on a basic neoclassical, linearly homogenous Constant Elasticity of Substitution (CES) production technology, $F(\cdot)$ to produce a uniform, tradeable output good, $Y$. The price of the output good is normalized to one and the firms in each sector are distinguished by the superscript $f \in\{C, N\}$.

$$
\begin{aligned}
Y^{f}=F\left(\bar{L}^{f}, K^{f}, E^{f}\right)= & A^{f}\left[d^{f} \bar{L}^{f,-\frac{1-\sigma}{\sigma}}+\left(1-d^{f}\right) K^{f,-\frac{1-\sigma}{\sigma}}+E^{f,-\frac{1-\sigma}{\sigma}}\right]^{\frac{-\sigma}{1-\sigma}} \\
\text { with } & F(0)=0 ; \quad F^{\prime}>0 ; \quad F^{\prime \prime}<0 .
\end{aligned}
$$

Labour, $\bar{L}$, capital, $K$, and a sector specific fixed factor, $E$, serve as input factors. ${ }^{5}$ The elasticity of substitution between input factors is denoted by $\sigma$ while $d$ denotes a preference parameter.

The variable, $\bar{L}$, resembles a labour composite in the form of a CES preference function consisting of low-, $L_{l}$, medium-, $L_{m}$, and high-skilled labour, $L_{h}$. The optimal composition of the different labour skill types, i.e. the unit labour demands, $l_{i}, i \in\{l, m, h\}$, follows from the cost minimization problem

$$
\begin{aligned}
\bar{w}^{f}=\min _{l_{i}^{f}, i \in\{l, m, h\}} & \sum_{i}^{3} w_{i} \cdot l_{i}^{f}, \\
\text { s.t. } & \bar{l}^{f}=\left\{\sum_{i}^{3}\left(\alpha_{i}^{f}\right)^{\frac{1}{1+\mu}}\left[l_{i}^{f}\right]^{\frac{\mu}{1+\mu}}\right\}^{\frac{1+\mu}{\mu}}=1 .
\end{aligned}
$$

The solution to eq. (2) yields optimal unit labour demands

$$
l_{i}^{f}=\frac{\alpha_{i}^{f}}{w_{i}^{1+\mu}\left[\sum_{i}^{3} \alpha_{i}^{f} \cdot w_{i}^{-\mu}\right]^{\frac{1+\mu}{\mu}}},
$$

\footnotetext{
${ }^{5}$ The fixed factor can be interpreted as a sector specific rent which assures the existence of some firms in the corporate and non-corporate sector even if the tax system heavily discriminates against one of these two legal forms.
} 
with $\alpha_{L i}^{f}, i \in\{l, m, h\}$ denoting the preference parameters for each skill type of labour ${ }^{6}$ and $\mu$ denoting the substitution elasticity between the different labour skill types. The overall labour demand for each skill type is finally computed by $L_{i}^{f}=\bar{L}^{f} \cdot l_{i}^{f}$.

Capital expands over time whenever gross investments, $I$, exceed depreciation, $\delta K$. The equation of motion for capital is thus determined by the amount of net investments, $I N .^{7}$

$$
G K_{t+1}^{f}=I_{t}^{f}+(1-\delta) K_{t}^{f} \quad \Leftrightarrow \quad G K_{t+1}^{f}-K_{t}^{f}=I_{t}^{f}-\delta K_{t}^{f}=I N_{t}^{f} .
$$

The variable $G$ which enters each differential equation denotes the exogenous trend growth in labour productivity, $G=1+g$. Accordingly, in the balanced growth equilibrium all variables grow at the rate $g$.

Investments additionally incur adjustment costs of $J(I, K)$ for each unit of capital installed. The adjustment costs reflect positive but diminishing marginal returns to capital formation and can be interpreted as the costs arising due to a firm's internal reorganization if the firm expands.

$$
\begin{aligned}
& J^{f}=J\left(I^{f}, K^{f}\right)=I^{f} \cdot J_{I}^{f}+K^{f} \cdot J_{K}^{f}, \\
& \text { with } \quad J_{I}>0 ; \quad J_{I I}>0 ; \quad J_{I I}<0 \text {. }
\end{aligned}
$$

The adjustment cost function is linearly homogenous in investment and capital and convex in investments. The steady state adjustment costs are zero and do not influence the steady state solution.

\subsection{Financial Identities \& Arbitrage}

Corporate firms have access to three different sources of funds encompassing new debt, $B N$, new share issues, $V N$, and retained earnings, $(\pi-D)$ when financing their net investment outlays, $I N^{C}$. Retained earnings are defined as profits, $\pi$, less dividend payouts,

\footnotetext{
${ }^{6}$ The empirical evidence on the wage rates and the employment of the different labour skill types across sectors allows us to calibrate the preference parameters $\alpha_{i}, i \in\{l, m, h\}$, according to $\alpha_{i}^{f}=l_{i}^{f} \cdot w_{i}{ }^{1+\mu} /\left[\sum_{i}^{3} l_{i}^{f} \cdot w_{i}\right]^{1+\mu}$.

${ }^{7}$ Gross investments, $I$, are defined by net investment, $I N$, plus replacement investments, $\delta K$.
} 
$D$. Thus, the flow of funds equation which specifies the use and source of funds states ${ }^{8}$

$$
I N_{t}^{C}=B N_{t}^{C}+V N_{t}^{C}+\left(\pi_{t}^{C}-D_{t}^{C}\right)
$$

Debt financing is, however, not costless but gives rise to agency cost of size, $m^{f}\left(b^{f}\right)$ in addition to debt interest. The total cost of debt financing thus amount to $i^{B, H}+m^{f}\left(b^{f}\right)$, with $i^{B, H}$ denoting the gross rate of interest paid on business bonds. The agency cost of debt finance are modelled as an increasing function of the firm's debt asset ratio $b_{t}^{f}=$ $B_{t}^{f} / K_{t}^{f},{ }^{9}$ reflecting the increased risk of bankruptcy, if a firm's indebtedness and thereby its real costs of default rise.

Defining the existing stock of debt by, $B$, and new debt incurred by, $B N$, the equation of motion for debt is given by

$$
G B_{t+1}^{f}=B_{t}^{f}+B N_{t}^{f}
$$

While the corporate firm's financing via debt or retained earnings is determined endogenously within the model, the amount of new share issues is set exogenously via the parameter $\beta$. Thus, the amount of new equity issued by corporate firms is given by

$$
V N_{t}^{C}=\beta \cdot I N_{t}^{C} \text {. }
$$

In case the government provides a write-off for investment expenditures eq. (8) changes to: $V N_{t}^{C}=\beta\left(1-z_{3} \tau^{P f}\right) I N_{t}^{C},\left(8^{\prime}\right)$. The variable $z_{3}$ denotes the share of investment expenditures subject to a write-off and $\tau^{P, f}$ is the corporate tax rate. If $z_{3}$ equals one, the tax system provides a full immediate write-off, while $z_{3}<1$ indicates that only the fraction $z_{3}$ of investment expenditures faces a beneficial tax treatment.

Contrary to corporate firms, non-corporate firms can solely rely on new debt and new share issues as investment funds since all profits - which constitute part of the entrepreneur's income - are immediately distributed to the firm owner, implying $\pi^{N}=$

8 The flow of funds equation refers to only net investments as we assume that replacement investments are always financed internally via retained earnings.

${ }^{9}$ The agency cost of debt are increasing in the debt equity ratio. Accordingly, the first, $m_{f}^{\prime}(b)$, and the second, $m_{f}^{\prime \prime}(b)$, derivative of the agency cost function are positive. 
$D^{N} \cdot{ }^{10}$ Therefore, the flow of funds equation for non-corporate firms reads

$$
I N_{t}^{N}=V N_{t}^{N}+B N_{t}^{N}
$$

Having defined the financial behaviour of corporate and non-corporate firms, net of tax profits of either firm are determined by output less adjustment costs, $J^{f}$, less the sum of wage payments, $\sum_{i}^{3} w^{i} L^{f, i}$, with $i \in\{l, m, h\}$, less depreciation, $\delta K^{f}$, less the cost of debt finance, $\left(i^{B H}+m^{f}\right) B^{f}$, and less the firm's tax liability, $T^{P, f}$

$$
\pi^{f}=Y^{f}-J^{f}-\sum_{i}^{3} w^{i} L^{f, i}-\delta K^{f}-\left(i^{B H}+m^{f}\right) B^{f}-T^{P, f} .
$$

The firm's tax liability follows from the existance of the corporate $\operatorname{tax}, \tau^{P, C}$, which has to be interpreted as a source tax on firm profits, in case of corporate firms - or as the personal income tax of the firm owner, $\tau^{P, N}$, if non-corporate firms are considered. While adjustment costs, agency costs, labour costs and depreciation are fully tax deductible, we introduce two additional tax parameters, $z_{1}$ and $z_{2}$ (in additiona to $z_{3}$ ) which identify the possibility to additionally deduct debt interest or an imputed return, $i^{E}$, on equity capital, respectively, from the profit tax base. Hence a firm's tax liability states

$$
\begin{aligned}
T^{P, f}= & \tau^{P, f}\left[Y^{f}-J^{f}-m^{f} B^{f}-\sum_{i}^{3} w^{i} L^{f, i}-\delta K^{f}\right. \\
& \left.-z_{1} i^{B H} B^{f}-z_{2} i^{E}\left(K^{f}-B^{f}\right)-z_{3} I N^{f}\right] .
\end{aligned}
$$

If all three tax parameters, $z_{1}, z_{2}$ and $z_{3}$, are set to zero, neither debt interest nor an imputed return on equity capital are tax deductible, nor does a tax allowance for net investment expenditures exist. In our benchmark calibration we assume $z_{1}$ to be equal to one and $z_{2}$ to be zero, implying that only debt interest is tax deductible as it is the case in nearly all OECD countries.

The net of tax return on real investments, i.e. on firm equity, $r^{V, f},{ }^{11}$ consists of net of tax dividends and net of tax capital gains. The latter are defined by the change in the

\footnotetext{
${ }^{10}$ Regarding non-corporate firms, here the owner and the investor are one and the same person. Therefore, all profits of non-corporate firms are considered as personal income, independently of whether they are distributed or not. Moreover, no further dividend tax is imposed on the distribution of non-corporate firms, $\tau^{D, N}=0$, such that the optimal strategy implies to distribute the entire profits $D^{N}=\pi^{N}$.

${ }^{11}$ Even though we notionally distinguish between the net return on corporate and noncorporate equity, we assume both assets to be perfect substitutes and thus to yield the same rate of return, $r^{V, C}=r^{V, N}$.
} 
firm value, $G V_{t+1}-V_{t}$, less new equity injections, $V N$.

$$
r_{t}^{V, f} V_{t}^{f}=\underbrace{\left(1-\tau^{D, f}\right)}_{\theta^{D, f}} D_{t}^{f}+\underbrace{\left(1-\tau^{G, f}\right)}_{\theta^{G, f}}\left[G V_{t+1}^{f}-V_{t}^{f}-V N_{t}^{f}\right] .
$$

The variable $V$ denotes the firm value while $\tau^{D, f}$ and $\tau^{G, f}$ label the personal tax on dividend income and the capital gains tax, respectively. For the sake of convenience, we apply tax factors represented by $\theta$ instead of tax rates. Each tax factor is defined by one minus the respective tax rate. Since the distributions of non-corporate firms are not subject to the dividend tax the tax parameter $\theta^{D, N}$ in case of non-corporate firms is one. The firm value of either firm type ${ }^{12}$ at any period $t$ can be assessed by rearranging and solving forward eq. (12).

$$
V_{t}^{f}=\sum_{S=t}^{\infty} \overbrace{\frac{\theta^{D, f}}{\frac{\theta}{G, f}^{f} D_{S}^{f}-V N_{S}^{f}}}^{\chi_{S}^{S}} \prod_{Z=t} \frac{1+g}{1+r_{S}^{e, f}},
$$

with $r^{e, f}=r^{V} / \theta^{G, f}$ and $\chi_{s}^{f}=\theta^{D, f} / \theta^{G, f} D_{s}^{f}-V N_{s}^{f}$. As we learn from (13) the firm value is determined by the discounted sum of all future tax adjusted net distributions to firm owners. The extensive form of these net distributions is obtained by inserting eq.(6), (8'), (10) and (11) into the expression for $\chi^{f}$

$$
\begin{aligned}
\chi_{t}^{f} & =\gamma^{D, f}\left\{Y^{f}-J^{f}-\sum_{i}^{3} w^{i} L^{f, i}-\delta K^{f}-m^{f} B^{f}-\frac{\left(1-z_{1} \tau^{P, f}\right)}{\theta^{P, f}} i^{B} B^{f}\right. \\
& \left.+z_{2} \frac{\tau^{P, f}}{\theta^{P, f}} i^{E}\left(K^{f}-B^{f}\right)\right\}+\Omega^{f} B N^{f}-\gamma^{I, f} I N^{f} .
\end{aligned}
$$

The firm specific tax parameters for corporate and non-corporate firms, $\gamma^{D, f}, \gamma^{I, f}$ and $\Omega^{f}$, are defined as reported in Table 1

Table 1: Tax Parameters

\begin{tabular}{rll}
\hline \multicolumn{1}{c}{ Corporate Firms } & Non-Corporate Firms \\
\hline$\gamma^{D, C}=\left(\theta^{D, C} \theta^{P, C}\right) / \theta^{G, C}$ & $\gamma^{D, N}=\theta^{P, N} / \theta^{G, N}$ \\
$\gamma^{I, C}=\left[{\frac{\theta}{\theta^{D, C}}}_{\theta^{G, C}}(1-\beta)+\beta\right]\left(1-z_{3} \tau^{P, C}\right)$ & $\gamma^{I, N}=1-\frac{z_{3} \tau^{P, N}}{\theta^{G, N}}$ \\
$\Omega^{C}=\theta^{D, C} / \theta^{G, C}$ & $\Omega^{N}=1$ \\
\hline
\end{tabular}

${ }^{12}$ The differential equation for the firm value is

$$
\left(1+r e_{t}^{V, f}\right) V_{t}^{f}=\theta^{D, f} / \theta^{G, f} D_{t}^{f}-V N_{t}^{f}+G V_{t+1}^{f} \text {. with } r^{e, f}=r^{V} / \theta^{G, f}
$$




\subsection{Optimal Intertemporal Responses}

Firms maximize their value by choosing the lowest cost labour composite, optimal investments and an optimal financial program. The firm value itself is a positive function of the amount of capital accumulated but declines with the level of debt inherited. Keeping in mind that a firm can only affect its end of period firm value, $V_{t}^{e, f} \equiv\left(1+r_{t}^{e, f}\right) V_{t}^{f}$, with it's current actions in period $t$, the intertemporal problem (Bellman Equation) states

$$
\begin{aligned}
V^{e, f}\left(K_{t}^{f}, B_{t}^{f}\right)=\max _{\bar{L}^{f}, I^{f}, B N^{f}} & {\left[\chi_{t}^{f}+\frac{G}{1+r_{t+1}^{e, f}} V^{e, f}\left(K_{t+1}^{f}, B_{t+1}^{f}\right)\right] } \\
\text { s.t. } & (4) \text { and }(7)
\end{aligned}
$$

The shadow prices of capital, $q_{t}^{e, f} \equiv d V_{t}^{e, f} / d K_{t}^{f}$, and debt, $\lambda_{t}^{e, f} \equiv d V_{t}^{e, f} / d B_{t}^{f}$, are defined as the marginal change in the firm value, if one additional marginal unit of capital and debt, respectively, are accumulated. The solution to the intertemporal maximization problem is given by the respective optimality condition for each of the control variables which are the different labour skill types, $L_{i}$, investment, $I$, and new debt, $B N$

$$
\begin{array}{rlrl}
\text { (a) } L_{i, t}^{f}: & w_{t}^{i}=F_{L_{i}, t}^{f}, & \text { with } i \in\{l, m, h\}, \\
\text { (b) } I_{t}^{f}: & \frac{q_{t+1}^{e, f}}{\left(1+r e_{t+1}^{f}\right)}=q_{t+1}^{f}=\left[\gamma^{I, f}+\gamma^{D, f} J_{I}^{f}\right], \\
\text { (c) } B N_{t}^{f}: & \frac{\lambda_{t+1}^{e, f}}{\left(1+r e_{t+1}^{f}\right)}=\lambda_{t+1}^{f}=-\Omega^{f} .
\end{array}
$$

The optimal demand for each skill type of labour is determined by the equality between the skill specific marginal product of labour, $F_{L_{i}}^{f}$ and the corresponding labour cost $w^{i}$.

The second optimality condition (16b) defines the firm's optimal investment policy: it requires that the present value of the marginal benefit stemming from one additional unit of capital tomorrow, $q_{t+1}^{f}$, is identical to the incurred marginal cost for carrying out this investment today. The incurred cost of the marginal investment includes the tax adjusted cost of the investment, $\gamma^{I, f}$, as well as adjustment costs of size $\gamma^{D, f} J_{I}^{f}{ }^{13}$

The optimal strategy of raising new debt implies that debt is the preferred source of funds as long as the additional gain from each unit of debt, $\left|\lambda_{t+1}^{f}\right|$, is larger or equal to the resulting cost of using debt, $\Omega^{f}$, as determined in (16c).

\footnotetext{
${ }^{13}$ In a world without taxation the optimality condition (16b) simplifies to $\left[1+J_{I}^{f}\right]$ in the phase of transition and to 1 in the steady state, when adjustment costs are zero. Hence, the model yields the standard investment criterion known from the neoclassical theory.
} 
The envelope conditions for the stock variables capital (17a) and debt (17b) are

(a) $q_{t}^{e, f}=\gamma^{D, f}\left[F_{K}^{f}-J_{K}^{f}+m_{f}^{\prime} b_{f}^{2}+z_{2} \frac{\tau^{P, f}}{\theta^{P, f}} i^{E}\right]-\left(\gamma^{D, f}-\gamma^{I, f}\right) \delta+\frac{q_{t+1}^{e, f}}{1+r_{t+1}^{e, f}}(1-\delta)$,

(b) $\lambda_{t}^{e, f}=\gamma^{D, f}\left[-\frac{1-z_{1} \tau^{P, f}}{\theta^{P, f}} i^{B}-z_{2} \frac{\tau^{P, f}}{\theta^{P, f}} i^{E}-m_{f}-m_{f}^{\prime} b_{f}\right]+\frac{\lambda_{t+1}^{e, f}}{1+r_{t+1}^{e, f}}$.

In detail, the shadow price of capital defines the value of an induced marginal profit. Adding one more unit of capital creates a marginal profit stream consisting of several components: first, the additional unit of capital earns the marginal product of capital, $F_{K}$, - but, second, as capital accumulation involves adjustment costs. These costs, $J_{K}$, diminish the marginal profit stream. Third, the additional investment strengthens the firm's equity base such that agency costs of debt decline by $m_{f}^{\prime} b_{f}^{2}$. Forth, if the opportunity cost of equity capital are tax deductible $\left(z_{2}>0\right)$, each additional unit of capital installed generates a positive tax benefit of size $\left(z_{2} \tau^{P, f} i^{E}\right) / \theta^{P, f}$.

The costs of one additional unit of debt are determined by the shadow price of debt and include debt interest which may or may not be tax deductible (the first two terms in squared brackets of (17b)), and the augmented agency cost of debt (third and fourth term in squared brackets of $(17 \mathrm{~b}))$.

In the next section we combine each of the two envelope conditions with the respective optimality conditions to derive the cost of capital under the different financial strategies a firms can access.

\subsection{Financial \& Investment Behaviour}

From the famous theorem by Modigliani and Miller (1958), we have learned that in a world of perfect capital markets and no taxes, the optimal investment rule is independent of the source of financing underlying the investment project. In the presence of taxation and agency costs this theorem is, however, no longer valid. Tax provisions may create a preference for specific forms of financing and may result in severe under- or overinvesting.

Financial Behaviour In order to derive the optimal financial behaviour of the representative firms, we combine the envelope condition eq. (17b) with the definition for the 
shadow price of debt as given in (16c) and get

$$
r^{e, f}-z_{2} \frac{\gamma^{D, f}}{\Omega^{f}} \frac{\tau^{P, f}}{\theta^{P, f}} i^{E}=\frac{\gamma^{D, f}}{\Omega^{f}}\left[\frac{1-z_{1} \tau^{P, f}}{\theta^{P, f}} i^{B}+m_{f}+m_{f}^{\prime} b_{f}\right] .
$$

Accordingly, the optimal level of debt is determined by the equality between the cost of equity finance (left hand side of (18)), and the cost of debt finance (right hand side of (18)). The cost of equity are given by the net of tax return required on firm equity, $r^{e, f}$. In case the tax system features an Allowance for Corporate Equity $(\mathrm{ACE})^{14}$, implying $z_{2}>0$, the required return on equity capital may even be lower than $r^{e, f}$.

The effective costs of debt financing encompass debt interest and agency cost of debt, $m_{f}+m_{f}^{\prime} b_{f}$. Debt financing may carry a tax benefit, if debt interest is tax deductible, i.e. if $z_{1}>0$. In case $z_{1}=1$ the return of the marginal debt financed investment project is tax free, i.e. the corporate tax does not distort the investment decision under debt financing. An increased indebtedness, however, involves rising agency costs of debt finance since banks charge a higher premium, if firm's indebtedness and thus their risk of bankruptcy has increased. ${ }^{15}$

Investment Behaviour Combining the expression for the shadow price of capital (17a) with the optimality condition determining investment behaviour (16b) we are able to derive an expression for the firm's cost of capital

$$
F_{K}^{f}-\delta=r_{t}^{e, f} \frac{\gamma^{I, f}}{\gamma^{D, f}}-z_{2} \frac{\tau^{P, f}}{\theta^{P, f}} i_{t}^{E}-m_{f}^{\prime} b_{f}^{2}
$$

Next, by inserting the expression specifying the optimal financial behaviour, eq. (18), into the above equaion, the firm's cost of capital can be expressed as the weighted sum of the cost of equity capital and external debt capital, whith the debt asset ratio, $b_{f}$, serving as a weighting factor.

$$
F_{K}^{f}-\delta=\underbrace{\left\{\frac{r_{t}^{e, f}}{\gamma^{D, f}}\right\}\left(\gamma^{I, f}-\Omega^{f} b_{f}\right)}_{\text {cost of equity }}+\underbrace{\left\{\frac{1-z_{1} \tau^{i P, f}}{\theta^{P, f}} i^{B H}+m_{f}\right\} b_{f}}_{\text {cost of debt }}-\underbrace{z_{2} \frac{\tau^{P, f}}{\theta^{P, f}}\left(1-b_{f}\right) i_{t}^{E}}_{\text {adv. of ACE }}
$$

\footnotetext{
${ }^{14} \mathrm{An}$ Allowance for Corporate Equity (ACE) tax system features a tax deduction for an imputed return on equity capital making sure that debt and equity are treated equally from a tax ponit of view.

${ }^{15}$ The comparative static analysis shows, that an increase in the corporate tax rate or in the personal income tax rate increases the tax advantage of debt finance, if interest expenditures are tax deductible, i.e. $\frac{d b^{C}}{d \tau^{P, C}}=\frac{r^{V} /\left[\left(1-\tau^{G, C}\right)\left(1-\tau^{P, C}\right)^{2}\right]}{\left[2 m^{\prime}(b)+m^{\prime \prime}(b)\right]}>0$ and $\frac{d b^{N}}{d \tau^{P, N}}=\frac{r^{V} /\left(1-\tau^{P, N}\right)^{2}}{\left[2 m^{\prime}(b)+m^{\prime \prime}(b)\right]}>0$.
} 
In the absence of taxation, an investment in firm equity must offer a rate of return at least equal to its opportunity cost, namely the rate of interest. With taxation, the cost of capital turns out to be, however, much more complex as shown in (20). The first term on the right hand side determines the cost of equity finance. The second term, the cost of debt finance, consists of interest payments plus the agency cost. The last term indicates the advantage of an ACE, in case $z_{2}>0$. The propensity to undertake additional investments depends on the tax allowance for investments $z_{3}$ which is captured in $\gamma^{I, f}$. This term encompasses both depreciation for tax purposes and direct investment premia.

The distinct and more concise formulae which clearly depict the difference between the cost of capital for corporate and non-corporate firms, respectively are given by eq.(21) and eq. $(23)$.

Corporate Firms: By inserting the relevant tax parameters for corporate firms into eq.(20) we derive the following cost of capital formula for firms belonging to the corporate sector. $^{16}$

$$
F_{K}^{C}-\delta=\frac{r^{V}}{\theta^{G, C} \theta^{P, C}}\left(1-b_{C}\right)+\left(i^{B H}+m_{C}\right) b_{C}
$$

The comparative static analysis of (21) shows that an increase in the corporate and the capital gains tax rate has a negative effect on the investment behaviour of corporate firms, since both tax rates augment the cost of capital. ${ }^{17}$

$$
\begin{aligned}
\frac{d\left(F_{K}^{C}-\delta\right)}{d \tau^{P, C}} & =\frac{r^{V}}{\left(1-\tau^{G, C}\right)\left(1-\tau^{P, C}\right)^{2}}\left(1-b_{C}\right)>0, \\
\frac{d\left(F_{K}^{C}-\delta\right)}{d \tau^{G, C}} & =\frac{r^{V}}{\left(1-\tau^{G, C}\right)^{2}\left(1-\tau^{P, C}\right)}\left(1-b_{C}\right)>0 .
\end{aligned}
$$

An increase in the corporate tax rate implies a higher tax burden on the returns from real investment projects compared to those from a financial investment which is not subject to

\footnotetext{
${ }^{16}$ The tax parameters for corporate firms are $\gamma^{D, C}=\left(\theta^{D, C} \theta^{P, C}\right) / \theta^{G, C}$ and $\gamma^{I, C}=\Omega^{C}=$ $\theta^{D, C} / \theta^{G, C}$. In addition, we disregard new share issues $(\beta=0)$ and assume that depreciation follows economic depreciation $\left(z_{3}=0\right)$. Furthermore, we allow debt interest to be deductible $\left(z_{1}=1\right)$ but not equity capital $\left(z_{2}=0\right)$.

${ }^{17}$ For the comparative static analysis we assume that firm's financial behaviour is optimal ex ante, such that a marginal change in any tax rate has no influence on the firm's optimal debt asset ratio, $b$.
} 
the corporate tax but to the personal tax on interest income. Therefore, investors have an incentive to put their money in financial instead of real investment projects. This negative effect resulting form an increase in the corporate tax is larger for those firms endowed with much equity capital but smaller for highly indebted firms (since debt interest is tax deductible).

In case the capital gains tax is increased, profit retentions are less favored compared to debt financed investments. Thus, the cost of capital increases to the extent profit retentions are used as a marginal source of finance. ${ }^{18}$

Non-Corporate Firms: To derive the distinct cost of capital formula for non-corporate firms we insert the respective tax parameters for non-corporate firms ${ }^{19}$ into the cost of capital formula displayed in (20).

$$
F_{K}^{N}-\delta=\frac{r^{V}}{\theta^{P, N}}\left(1-b_{N}\right)+\left(i^{B H}+m_{N}\right) b_{N}
$$

The striking difference to the cost of capital of corporate firms is that the capital gains tax rate does not appear in this expression. This is the case, since non-corporate firms can not draw on retained earnings as a source of finance. Similar to the comparative static analysis carried out for corporate firms, a rise in the personal income tax rate has a negative impact on the level of investments carried out by non-corporate firms since this tax increase raises the cost of capital.

\subsection{Household Sector}

The representative household is modelled in the spirit of an infinitely lived Ramsey agent, who takes the discounted utility of all future generations into account. The weight assigned

\footnotetext{
${ }^{18}$ The effect of a change in the tax rate on interest income depends on the degree of substitution between assets. Since we model assets to be imperfect substitutes, a rise in the interest tax rate will induce an increase in the demand for corporate equity only insofar as the substitution elasticity between assets is high.

${ }^{19}$ The tax parameters for non-corporate firms state: $\gamma^{D, N}=\theta^{P, N} / \theta^{G, N}, \gamma^{I, N}=1-\left[\tau^{P, N}\right.$ $\left.z_{3} / \theta^{G, N}\right]$ and $\Omega^{N}=1$. Moreover, similar to the case of corporate firms, we set $z_{1}=1, z_{2}=0$ and $z_{3}=0$ when computing the cost of capital for non-corporate firms.
} 
to each future generation is denoted by $\rho^{H}<1 .^{20}$ The preferences of our representative household are characterized by

$$
\begin{aligned}
U_{t} & =u\left\{Q_{t}\right\}+\rho^{H} \cdot U_{t+1}=\sum_{s=t}^{\infty} \rho^{H, s-t} \cdot u\left\{Q_{S}\right\}, \\
\text { with } \quad Q_{t} & =C_{t}-\sum_{i}^{3} \varphi\left(l_{i, t}^{S}\right), \quad i \in\{l, m, h\} .
\end{aligned}
$$

The variable $Q$ denotes individual consumption less the disutility of work arising for each of the tree skill types of labour, $l_{i}^{S}$, supplied. Accordingly, the household's life-time utility is a function of consumption, $C$, less the disutility of work $\sum_{i}^{3} \varphi\left(l_{i, t}^{S}\right)$.

The household maximizes (24) subject to her inter-temporal wealth constraint consisting of financial portfolio wealth, $A^{H}$, and disposable labour income, $y^{D}$, less consumption expenditures, gross of VAT $\left(1+\tau^{C}\right) C_{t}$

$$
\begin{aligned}
G A_{t+1}^{H} & =\left(1+\bar{r}_{t}\right) A_{t}^{H}+y_{t}^{D}-\left(1+\tau^{C}\right)\left[C_{t}-\sum_{i}^{3} \varphi\left(l_{i, t}^{S}\right)\right], \\
\text { with } \quad y_{t}^{D} & =\sum_{i}^{3}\left[\left(1-\tau^{L_{i}}\right) w_{i, t} L_{i, t}^{S}+\tau^{L_{i}} L T A_{i, t}\right]+T_{t}^{H}-\left(1+\tau^{C}\right) \sum_{i}^{3} \varphi\left(l_{i, t}^{S}\right) .
\end{aligned}
$$

The household's financial wealth includes several different asset types such that the household faces in addition to her utility maximization problem an optimal portfolio choice problem which is described in detail further below. Disposable labour income stems from net of tax labour income earned by each of the skill types of labour supplied. ${ }^{21}$ In addition the household receives a lump-sum transfer in the size of $T^{H}$.

Optimal Portfolio Choice The household can choose between different assets $A^{j, k}$ where the first superscript, $j \in\left\{V^{f}, B, D^{k}\right\}$, denotes the asset type, (equity, $V^{f}$, debt, $B$, or bonds, $D^{k}$,) and the second superscript, $k \in\{H, F\}$ the investor type (domestic, $H$, or foreign, $F$ ). In detail, domestic investors are entitled to hold domestic corporate or non-corporate equity, domestic and foreign business debt and government bonds.

$$
A^{H}=A^{V^{C}}+A^{V^{N}}+A^{B, H}+A^{D^{H}, H}+A^{D^{F}, H}
$$

\footnotetext{
${ }^{20}$ In case the Ramsey agent is seen as one single infinitively lived individual, the discount factor can be interpreted as the subjective rate of time preference. A high value for $\rho^{H}$ depicts a rather "inpatient" agent with a strong preference for current consumption while a low rate of time preference resembles a "patient" agent.

${ }^{21}$ The variable $L T A_{i}$ denotes a skill type specific Labour Tax Allowance.
} 
Foreign investors, however, just have access to domestic and foreign business debt and government bonds, since domestic firm equity is non-tradeable per assumption. ${ }^{22}$

Following the residence principle of taxation, all kinds of returns are taxed in the investor's country of residence. Thus, gross domestic and foreign interest rates are equalized, $i^{H}=i^{F}$, while net of tax rates of return differ between the domestic and the foreign economy. Since we additionally assume that the different types of assets are imperfect substitutes, the net rates of return on domestically owned assets do not equalize due to imperfect financial arbitrage. Given the relative rates of return of the different asset types, each household adjusts her portfolio holdings so as to maximize the average, net of tax portfolio return, $\bar{r}^{H}$.

$$
\bar{r}^{H}=\frac{r^{V}\left(A^{V^{C}}+A^{V^{N}}\right)+r^{B H} A^{B, H}+r^{H} A^{D^{H}, H}+r^{F} A^{D^{F}, H}}{A^{H}}
$$

In detail, domestic corporate and non-corporate firm equity, $A^{V^{C}}$ and $A^{V^{N}}$, - which are perfect substitutes - yield a rate of return of $r^{V}$. Domestic firm debt yields a gross rate of return of $i^{B H}$ which transforms into a net of tax rate of return of $r^{B H}=\left(1-\tau^{i}\right) i^{B H}$ with $\tau^{i}$ denoting the domestic tax on interest income. Domestic and foreign gross interest rates on government bonds are given by $i^{H}$ and $i^{F}$, and the respective net of tax rates are $r^{H}=\left(1-\tau^{i}\right) i^{H}$ and $r^{F}=\left(1-\tau^{i}\right) i^{F}$. Table 2 shows the gross and net returns on the different types of assets considered.

Table 2: Gross and Net Rates of Return

\begin{tabular}{lcl}
\hline Asset Type & Gross Return & Net Return \\
\hline Firm Equity & $i^{E}=\left[D^{f}+\left(G V_{t+1}^{f}-V_{t}^{f}-V N_{t}^{f}\right)\right] / V^{f}$ & $r^{V, f}, f \in\{C, N\}$ \\
Firm Bonds & $i^{B}$ & $r^{B}=\left(1-\tau^{i}\right) i^{B}$ \\
Dom. Gov. Bonds & $i^{D, H}$ & $r^{D, H}=\left(1-\tau^{i}\right) i^{D, H}$ \\
Foreign Gov. Bonds & $i^{D, G}$ & $r^{D, G}=\left(1-\tau^{i}\right) i^{D, G}$ \\
\hline
\end{tabular}

${ }^{22}$ This is an application of the so-called home bias which in trade theory is characterized by the Armington Assumption (ARMington 1969). The Armington assumption states that commodities exported and imported are imperfect substitutes of domestically used and produced commodities. This presumption can be extended to explain the predilection towards a higher weight of domestic assets in the investor's portfolio. This finding has been underlined among others by French and Poterba (1991) who show that in spite of the benefits of international diversification, most investors hold a large fraction of their wealth in domestic assets. 
In the long run, the net of tax average portfolio return has to equal the time preference for the home country, $\rho^{H}$, as required by the long-run stationary solution to the household maximization problem in the Ramsey model. A more detailed analysis of the portfolio choice problem and the capital market equilibrium can be found in Appendix A.

Intertemporal Optimization Returning to the households' maximization problem, the latter involves the optimal supply of low-, medium-, and high-skilled labour, as well as optimal intertemporal consumption behaviour. The household maximizes her utility as given by (24) subject to her intertemporal budget constraint, (25) from which we can derive the following optimality and envelope conditions

$$
\begin{aligned}
\text { (a) } l_{i}^{S}: \varphi^{\prime}\left(l_{i, t}^{S}\right) & =\frac{\left(1-\tau^{L_{i}}\right)}{\left(1+\tau^{C}\right)} w_{i, t}, \\
\text { (b) } Q: u^{\prime}\left(Q_{t}\right) & =\kappa_{t+1}\left(1+\tau_{t}^{C}\right) \rho^{H} / G, \quad=>\quad \kappa_{t+1}=\frac{G u^{\prime}\left(Q_{t}\right)}{\rho\left(1+\tau_{t}^{C}\right)}, \\
\text { (c) } A_{t}^{H}: & \kappa_{t}=\left[\rho^{H} \cdot\left(1+\bar{r}_{t}\right) / G\right] \kappa_{t+1} .
\end{aligned}
$$

Optimal labour supply, (28a), implies that the marginal disutility of work, resulting from the supply of each specific skill type has to be equal to the tax adjuststed compensation payment, i.e. the net of tax wage rate. Moreover, we assume a specific functional form for the disutility of work: $\varphi\left(l_{i}^{S}\right)=\gamma^{-1 / \varepsilon_{i}} \cdot l_{i}^{1+1 / \varepsilon_{i}} /\left(1+1 / \varepsilon_{i}\right)$, with $\gamma$ representing a scaling parameter and $\varepsilon_{i}$ the skill specific labour supply elasticity. ${ }^{23}$ Thus, the explicit expression determining optimal individal labour supply of each skill type is

$$
l_{i, t}^{S}=\gamma\left[\frac{\left(1-\tau^{L_{i}}\right)}{\left(1+\tau^{C}\right)} w_{i, t}\right]^{\varepsilon_{i}} .
$$

Aggregated labor supply is computed by $L_{i}^{S}=l_{i}^{S} \cdot N$, with $N$ denoting the size of the labor force.

The variable $\kappa_{t} \equiv \partial U_{t}^{*} / \partial A_{t}^{H}$ in eq. (28b) determins the marginal gain in the household's utility resulting from a marginal relaxation of her intertemporal budget constraint. Combining eq.(28b) and eq.(28c) we can derive the Euler equation which specifies the optimal intertemporal consumption pattern in the course of time

$$
\frac{u^{\prime}\left(Q_{t}\right)}{u^{\prime}\left(Q_{t+1}\right)}=\frac{1+\tau_{t}^{C}}{1+\tau_{t+1}^{C}} \frac{\rho^{H}\left(1+\bar{r}_{t+1}^{H}\right)}{G} .
$$

\footnotetext{
${ }^{23}$ This special form of preferences eliminates any income effects in the labour supply decision since labor supply solely depends on the current real wage.
} 
In order to derive an explicit expression for consumption expenditures (net of the disutility of work) we apply a $C E S$ utility function stating $u\left(Q_{t}\right)=Q_{t}^{1-1 / \sigma} /(1-1 / \sigma)$, with $\sigma$ denoting the intertemporal elasticity of substitution and constrain the optimal consumption profile (30) by the intertemporal budget constraint (25) such that

$$
\left(1+\tau_{t}^{C}\right) Q_{t}=m p c_{t} \cdot T W_{t}
$$

with $m p c_{t}$ and $T W_{t}$ denoting the marginal propensity to consume and total wealth, respectively. $^{24}$

Welfare Analysis As a measure for welfare, we apply the equivalent variation which specifies the differences in expenditures with respect to the before and after tax reform life-time utility levels $U^{0}$ and $U^{1}$, using the pre reform price structure $p^{0}$

$$
E V=T W\left(U^{0}, p^{0}\right)-T W\left(U^{1}, p^{0}\right)
$$

\subsection{General Macroeconomic Equilibrium}

Public Accounts: The government's total tax revenue, TTR, consists of tax receipts collected from the tax levied on corporate and personal income of corporate and noncorporate firms, $T^{P, f}$, labour income taxation, $T^{L_{i}}$, of the three different skill types of labour, ${ }^{25}$ interest income taxation, $T^{i}$, the taxation of dividend income, $T^{D}$, and capital gains, $T^{G}$, as well as the VAT revenue, $T^{C}$.

$$
T T R=\sum_{f}^{2} T^{P, f}+\sum_{i}^{3} T^{L_{i}}+T^{i}++T^{D}+T^{G}+T^{C} .
$$

Government expenditures include interest spending on public debt $\left(1+i^{H}\right) D^{G}$, government consumption, $C^{G}$, and lump-sum transfers to households, $T^{H}$. Government debt accumulates whenever expenditures exceed tax revenues collected.

$$
G D_{t+1}^{G}=\left(1+i^{H}\right) D_{t}^{G}+C_{t}^{G}+T_{t}^{H}-T T R_{t} .
$$

\footnotetext{
${ }^{24}$ See further details on the marginal propensity to consume and the composition of total wealth in Appendix B.

${ }^{25}$ As mentioned above, the labour tax is levied on labour income less a labour tax allowance, LTA. Total tax revenue collected from labour income thus equals $\sum_{i}^{3} \tau^{L_{i}}\left(w_{t}^{i} L_{i, t}^{S}-L T A_{i}\right)$.
} 
To rule out Ponzi-games we restrict expenditure increases to finance a budget deficit and restrict new debt to a maximum of three percent of GDP and government debt to GDP ratio to 60 percent. ${ }^{26}$ Hence, financial imbalances following a tax relief have to be offset by a future compensating action, i.e. a reduction in lump-sum transfers to households or an increase in any other tax rate.

Current Account In ifoMod we allow for two-way capital flows since domestic individuals can hold foreign government bonds $A^{D^{F}, H}$ and foreign individuals can own domestic firm $A^{B, F}$ and government bonds $A^{D^{H}, F} .27$ Thus, the gross national product, $G N P$, is given by $G D P$ plus net interest income from abroad.

$$
G N P=G D P+\underbrace{i^{F} A^{D^{F}, H}-i^{H}\left(A^{B, F}+A^{D^{H}, F}\right)}_{N C E_{t}=\text { net capital export }},
$$

Since we apply the residence principle of taxation, foreigners will earn the domestic gross return $i^{H}$ on their domestic assets and domestic investors the foreign gross return $i^{F}$ on their owned foreign government bonds. The cross ownership of assets is mirrored by the net foreign asset position which is defined for the home country as $N F A=A^{D F, H}-$ $\left(A^{B, F}+A^{D H, F}\right)$ which evolves over time according to

$$
G N F A_{t+1}-N F A_{t}=N C E_{t}+T B_{t}
$$

where $T B$ denotes the trade balance. The r.h.s. of eq.(36) determines the current account surplus defined as the excess of GNP over domestic absorption. The current account thus determines the accumulation of foreign wealth. By definition the trade deficit of one country has to equal the trade surplus of the other in a two country setting.

$$
T B=G D P-\sum_{f=C, N}^{2} I^{f}-C-C^{G} .
$$

\subsection{Calibration \& Macroeconomic Data}

The computational procedure of any numeric CGE model requires the specification of functional forms and the choice of appropriate behavioural parameters and elasticities

\footnotetext{
${ }^{26}$ These numbers depict the convergence criteria as laid down in the European Stability and Growth Pact (Articles 99[1] and 104[2] of the European Community Treaty).

${ }^{27}$ We assume here that foreign firms do not issue any bonds.
} 
from the empirical literature. In this context, the calibration implies that the initial steady-state of the model replicates the stationary long-run macroeconomic equilibrium of the considered economy. All behavioural parameters employed in ifoMod are standard results in line with the findings of the empirical literature as summarized in Table 3.

\section{Table 3: Behavioural Parameter Values}

Rate of Growth (BANDHOLZ et al. 2005)

Half-life of capital accumulation (in years) (Cummins et al. 1996)

Elasticity of factor substitution (GERMAn CENTral BANK 1995)

Elasticity of the debt-asset ratio (GORDON and LEE 2001)

Compensated Labor Supply Elasticity (FEHR 1999) (low-, medium-, high-skilled)

$0.49 / 0.54 / 0.59$

Intertemporal elasticity of substitution (FLAIG 1988)

The real annual growth rate of the German economy is assumed to be 1.1 per cent, which is, according to BANDHOLZ et al (2005), a fair estimate for Germany after reunification. Economic depreciation reaches 8 per cent of the capital stock and the adjustment speed towards the new steady state is determined by the half-life of investment. As in the study of CUMmins ET AL. (1996), we take a value of 8.0, implying that during the following 8 years after the policy shock half of the long-run increase in the capital stock is accumulated. ${ }^{28}$

One of the key parameters describing the production side of the economy, is the elasticity of substitution between labour and capital. The empirical literature offers extensive evidence on different estimates for this parameter. ${ }^{29}$ According to RoskAmp (1977), the elasticity of factor substitution for West German industries ranges between 0.3 and 1.3. We choose for the present study to apply a value of 0.8 which is based on estimates by the German Central Bank (1995).

\footnotetext{
${ }^{28}$ To achieve this pattern of the half life of investment, the adjustment cost parameter is set equal to 2. Such a value is also applied by Valkonen (1999) and represents a lower end value of available estimates (see Whited, 1994).

${ }^{29}$ Most estimates for the elasticity of factor substitution range between 0 and 1 , depending on the underlying estimation technique. For instance, the study by Chrinko, Fazzari and Meyer (1999) which is based on panel data, suggests an elasticity of 0.25 , whereas higher values of 0.7 for corporate and 0.5 for non-corporate capital are calculated by Jorgenson and Yun (2001) who apply capital stock data. A survey of these studies is provided by Chirinko (2002).
} 
For the value of the elasticity of the debt-asset ratio, we follow Gordon and LEE (2001), who estimate that a 10 percentage point decrease in the corporate tax rate leads to a reduction in the debt-asset ratio by about three to four per cent.

Even though the empirical literature on labour supply elasticities is manifold, the empirical evidence on the labour supply elasticities of different labour skill types is rather scarce. Therefore, we follow FEHR (1999), who computes compensated labour supply elasticities for the lowest, the third and the top quintile of earnings in Germany. Fehr's proposed data on the long-run labour supply elasticities for low-, medium-, and highskilled labour are $\varepsilon_{L}=0.49, \varepsilon_{M}=0.55$ and $\varepsilon_{H}=0.59$. Surprisingly, these figures are only slightly above the value of 0.51 which is proposed by FELDSTEIN (2005) as an applicable estimate for the average compensated labour supply elasticity in macro models.

Given the fact that the macroeconomic effects of capital income taxation are very sensitive to the choice of the intertemporal elasticity of substitution in consumption (see King and Rebelo (1990) or Summers (1981)), this parameter has to be set with great care. Our value of 0.4 is based on FLAiG's (1988) empirical research for Germany, and is just slightly lower than the values applied for instance by KEUsCHNiGG and DiETz (2004, 2007) or Valkonen (1999). Contrary to that, Auerbach and Kotlikoff (1987) applied a value of just 0.25 .

Macroeconomic Data Table 4 reports the main macroeconomic aggregates for Germany for the year 2005, the 5-year averages, and the aggregates replicated by our CGE model, ifoMOD.

Table 4: Replicated Macroeconomic Structure (in Bn. Euro)

\begin{tabular}{lccc}
\hline & $\begin{array}{c}\text { Germany } \\
2005\end{array}$ & $\begin{array}{c}\text { Medium Run } \\
\text { Average }\end{array}$ & ifoMOD \\
\hline GDP & 2244.6 & 2312.7 & $2244.6^{*}$ \\
Gross Capital Formation & 387.3 & 398.4 & 413.3 \\
Capital Stock & 6771.4 & 6776.4 & 6774.8 \\
Depreciation & 335.6 & 334.2 & 338.7 \\
Compensation of Employees & 1131.0 & 1146.7 & 1145.9 \\
Private Consumption & 1326.4 & 1330.1 & $1326.4^{*}$ \\
\hline Note: Variables marked by an * are set exogenously within the model. & \\
\hline
\end{tabular}

Source: Destatis (2005), own calculations. 
The size of the labour force, $N$, of 42.3 million people is computed as the product of the employment share 0.51 and the total German population of 82.5 million people. ${ }^{30}$ This number also matches the official German labour force data (DESTATIS 2005). To identify the relative sizes of the corporate and non-corporate sector within the economy, we use data from the $\mathrm{IAB}^{31}$ and compute a labour share of 65 per cent for the corporate sector. The remaining fraction of 35 per cent of the labour force is thus employed in the non-corporate sector.

\section{German Corporate Tax Reform of 2008}

In the following, we apply ifoMod to exemplify how it can be used to analyse the effects of a comprehensive tax reform. To this purpose, we consider a very recent rax reform, namely the latest German corporate tax reform which has been in place since the 1st of January 2008. In its basic features, this tax reform is aimed at both ensuring the international competitiveness of the German economy - by reducing the corporate tax burden - and at securing the German tax base by expanding the basis of assessment and limiting tax avoidance strategies. Thus the 2008 tax reform is not new in terms of being a tax-cut-cum base-broadening measure, but it rather mimics the US 1986 Tax Reform Act (Joint Committee on Taxation 1986). ${ }^{32}$

The German Corporate Tax Reform of $\mathbf{2 0 0 8}^{33}$ The core element of the 2008 tax reform is a cutback of the corporate tax rate by 10 percentage points and a reduction of the uniform trade tax measure from 5 to 3.5 percent such that the corporate firms' tax burden on retained earnings is reduced from initially 38.6 to 29.8 percent. Non-corporate firms, however, suffer from a slight tax increase. With the introduction of the so-called tax

\footnotetext{
${ }^{30} \mathrm{We}$ assume there is full employment in the economy.

${ }^{31}$ The Institut für Arbeitsmarkt und Berufsbildung (IAB) is a German research institute dealing with issues such as the German labour market and occupational training.

${ }^{32}$ Similar kinds of tax-cut-cum base-broadening reforms have also been introduced in numerous European states during the last few years. For example, Denmark adapted its tax system in 2001 and Italy in 1998 (CARONE AND SALOMÄKI 2001).

${ }^{33}$ A detailed survey on the German Corporate Tax Reform of 2008 is provided by the German Ministry of Finance (2007a, b).
} 
on the rich, the top personal income tax rate is increased by three percentage points from initially 42 to 45 percent. To provide for a tax relief for non-corporate firms, a reduced tax rate of just below 30 percent is levied on retained earnings of non-corporate firms. ${ }^{34}$

The second major aim of the reform - beside improving Germany's standing as an investment location - is to counteract the tax shifting activities by multinational enterprises via intra-company loans. Therefore, the base-broadening measures of the 2008 tax reform encompass the introduction of an interest stripping rule and the abolition of accelerated depreciation for fixed assets. In detail, the interest stripping rule limits the deduction of net-interest expenses for tax purposes to 30 percent of the EBIT. In order not to obstruct debt financing of small and medium sized firms, this rule applies only to those companies with more than Euro one million of net-interest expenses. ${ }^{35,36}$

Finally, from 2009 onwards, any income from capital such as interest, dividends and capital gains is subject to a final withholding tax of 25 percent (plus solidarity surcharge and church tax).

Table 5 provides an overview of pre- and post reform statutory tax rates we apply in our simulation analysis. The column Status Quo depicts the preexisting German tax system while the column Reform 2008 depicts the actual statutory tax rates prevailing after the enaction of the German corporate tax reform of 2008. The third column, labeled Reform Alternative, presents a slight variation of the 2008 tax reform by excluding capital gains from the final withholding tax.

\footnotetext{
${ }^{34}$ Any withdrawals from these retentions are, however, subject to additional taxation and hence the effective tax burden on distributions of non-corporate firms amounts to about 48 percent, i.e. to the top personal income tax rate plus the solidarity surcharge. These special tax provisions for non-corproate firms aim at equalizing the effective tax burden of firms of different legal form.

${ }^{35}$ As a counterdraw to these provisions, the former thin-capitalization rules which restricted tax deductibility of interest on related-party loans are to be repealed.

${ }^{36}$ Regarding the local trade tax, before the reform, half of the interest paid on permanent debt was added to the computation of taxable trade earnings. From now on, 25 percent of all interest paid (including short-term debts but no cash discounts and bonuses) and 25 percent of the notional "interest shares" for rent, leasing, licenses and leasing rates are added to the computation of taxable income.
} 
Table 5: Statutory Tax Rates (in \%)

\begin{tabular}{lccc}
\hline & Status Quo & Reform 2008 & Reform Alternative \\
\hline Corporate Firms & 38.6 & 29.8 & 29.8 \\
Non-Corporate Firms & 45.7 & 47.4 & 47.5 \\
Interest Income & 44.3 & 25.0 & 25.0 \\
Dividend Income & 22.1 & 25.0 & 25.0 \\
Capital Gains & 0.0 & 12.5 & 0.0 \\
Labour Income*) & $17.3 / 30.2 / 45.7$ & $17.3 / 30.2 / 47.4$ & $17.3 / 30.2 / 47.4$ \\
\hline${ }^{*)}$ Av. tax burden on low-, med.- and high-skilled labour with taxable income of $€ 15.000, € 50.000$ and above. \\
\hline
\end{tabular}

Source: German Ministry of Finance (2004, 2006 a,b) own calculations.

As one can see, the reform brought about a major tax reduction on interest income which was, prior to the reform, subject to the personal income tax of 44.3 percent. The tax burden on dividends increased only slightly form 22.1 to 25 percent since dividends benefited from the so-call half-imputation system before the reform. ${ }^{37}$ Capital gains were tax exempt before the reform but they are subject to the final withholding tax of 25 percent from 2009 onwards. Since capital gains are taxed upon realization and not on an accrual basis we, however, apply an (effective) tax rate of just half the statutory tax rate, i.e. a tax of 12.5 percent for capital gains. This approach is in line with the calculations done by the Ruding Committee (OECD 1991).

The applied personal income tax rates of low- and medium-skilled labour (associated with an annual income of up to Euro 15,000 and between Euro 15,000-50.000) amount to 17.3 and 30.2 percent, respectively.

Moreover, we model the interest stripping rule by adding 30 percent of incurred debt interest when computing the corporate tax liability. ${ }^{38}$ In case of non-corporate firms we abstain from the interest stripping rule since the latter just applies when net-interest expenses exceed a threshold of Euro one million. ${ }^{39}$

\footnotetext{
${ }^{37}$ With the introduction of the final withholding tax the preexisting half-income principle (only half of distributed profits are subject to the personal income tax) and the tax exemption for capital gains held beyond a one-year speculation time limit has been abolished.

${ }^{38}$ Stated differently, only 70 percent of debt interest are tax deductible such that we set $z_{3}=0.7$ for corporate firms.

${ }^{39}$ For further discussion of the impact of the interest stripping rule for German corporate and non-corporate firms see Maiterth and MüLler (2007), page 65.
} 
Simulation Results Table 6 reports the effective tax burden and the cost of capital for German firms before and after the 2008 reform. We find that the reform results in a slight increase in the tax burden on both German corporate and non-corporate firms. Albeit the major drop in the corporate firm's tax burden at firm level $(-20.1$ percent), which is measured by the so-called investment wedge, the effective tax burden for corporate firms increased by 4.2 percent. ${ }^{40}$ This rise in the effective tax burden is explained by the taxation of capital gains via the final withholding tax and the introduction of the interest stripping rule. Both elements overcompensate the reduction in the corporate tax such that the higher effective tax burden results in a slight increase in the cost of capital of corporate firms. Non-corporate firms are negatively affected by the introduction of the tax on the rich such that the effective tax burden and cost of capital for non-corporate firms slightly increase by 0.8 and 0.6 percent, respectively. Since the rise in the tax burden for corporate firms is more pronounced than for non-corporate firms, we expect the 2008 reform to have especially negative repercussions on the activity of corporate firms (but not for non-corporate firms).

Table 6: Effective Tax Burden and Cost of Capital (in \%)

\begin{tabular}{ccc|cc}
\hline & \multicolumn{2}{c|}{ Reform 2008} & \multicolumn{2}{c}{ Reform Alternative } \\
& C-Firms & N-Firms & C-Firms & N-Firms \\
\cline { 2 - 5 } Investment Wedge & $36.7 \rightarrow 29.4$ & $43.1 \rightarrow 44.8$ & $36.7 \rightarrow 29.4$ & $43.1 \rightarrow 44.8$ \\
\%-age change & $-20,1$ & +4.2 & $-20,1$ & +4.2 \\
Effective Tax Burden & $39.2 \rightarrow 40.8$ & $44.0 \rightarrow 44.4$ & $39.2 \rightarrow 35.5$ & $44.0 \rightarrow 45.0$ \\
\%-age change & +4.2 & +0.8 & -9.5 & +2.3 \\
Cost of Capital & $9.8 \rightarrow 10.1$ & $9.1 \rightarrow 9.2$ & $9.8 \rightarrow 9.2$ & $9.1 \rightarrow 9.3$ \\
\%-age change & +2.8 & +0.6 & -5.8 & +1.8 \\
\hline
\end{tabular}

Source: own calculations using ifoMod.

In an alternative scenario, we assume capital gains to be tax exempt. Consequently, the effective tax burden and the cost of capital of corporate firms decline by 9.5 and 5.8 percent, respectively, as a result of the lower profit tax. Thus, we would expect such a

\footnotetext{
${ }^{40}$ While the investment wedge contains solely taxes levied at the firm level, personal taxes are additionally taken into account when computing the effective tax burden on the investment activity.
} 
reform alternative to have a stimulating impact on the corporate firms' activity and, given the general equilibrium framework, negative effects for non-corporate firms.

The short- and long-run economic impact of the reform is presented in Table 7. Here, an additional advantage of a dynamic CGE model becomes clear. By means of such a model, we can distinguish between short- and long-run effects, which, as can be seen in the following, can differ to a great extent, and which can not be shown by means of a static model.

As expected, the 2008 reform harms corporate firms' activity, i.e. corporate investments and labour demand decline by more than 10 percent each in the long-run and hence corporate firms' output drops by 8.8 percent. Since non-corporate firms tax treatment is almost unaffected by the reform, general equilibrium effects push production factors into the non-corporate sector. Investments and labour demand of non-corporate firms increase by more than 11 and almost 12 percent, respectively, and non-corporate output grows by almost 11 percent in the long-run.

The increased activity in the non-corporate sector, however, cannot absorb the decline in economic activity in the corporate sector. The overall investment activity declines by 3.2 percent, labour demand falls short by 1 percent and total output shrinks by almost two percent. Moreover, the shrinking of the corporate sector leads to a lower demand of workers, in particular high-skilled labour, which is not - contrary to low- and mediumskilled labour - fully absorbed by the non-corporate sector.

The welfare loss accompanying the 2008 tax reform amounts to around one percent of GDP which corresponds to about two percent of the household's wealth. Stated differently, German households loose 1.9 percent of their wealth due to the implementation of the German corporate tax reform of 2008. The loss in welfare is explained by the enormous financial costs associated with the reform. In the short-run, more than Euro 35.6 billion are necessary to finance the reform. In order to balance the government budget, the financial need translates into a cut in transfers to households and therewith household's consumption declines by five percent in the short-run. In the long-run when economic activity has recovered, the financial costs of the reform amount to only Euro 1.4 billion. 
Table 7: Long-run Impact of the 2008 Tax Reform (in \%)

\begin{tabular}{|c|c|c|c|c|c|c|}
\hline & \multicolumn{3}{|c|}{ Reform 2008} & \multicolumn{3}{|c|}{ Reform Alternative } \\
\hline & total & C-Firms & N-Firms & total & C-Firms & N-Firms \\
\hline GDP & -1.9 & -8.8 & 10.9 & 1.4 & 11.5 & -17.5 \\
\hline Investments & -3.2 & -10.5 & 11.2 & 3.4 & 14.4 & -18.1 \\
\hline Labour Demand & -1.0 & -10.5 & 11.8 & & 10.2 & -15.5 \\
\hline - High-Skilled & -3.6 & -11.4 & 8.1 & 0.8 & 9.3 & -19.1 \\
\hline - Medium-skilled & -0.03 & -7.2 & 13.2 & 0.9 & 9.5 & -17.8 \\
\hline - Low-Skilled & 0.0 & -6.2 & 14.5 & 0.25 & 8.8 & -19.5 \\
\hline Welfare $^{1)}$ & \multicolumn{3}{|c|}{$-1.1(-1.9)$} & \multicolumn{3}{|c|}{$-0.3(-0.5)$} \\
\hline Consumption $^{2)}$ (in \%) & \multicolumn{3}{|c|}{$-5.0 /+2.7$} & \multicolumn{3}{|c|}{$-4.6 /+8.1$} \\
\hline Budget Deficit ${ }^{2}$ (Bil. €) & \multicolumn{3}{|c|}{$-35.6 /-1.4$} & \multicolumn{3}{|c|}{$-59.8 /+33.3$} \\
\hline Annuity of Deficit & \multicolumn{3}{|c|}{ - 14.9 Bil. € per year } & \multicolumn{3}{|c|}{-7.8 Bil. $€$ per year } \\
\hline
\end{tabular}

Source: own calculations using ifoMod.

Households' consumption recovers in the long-run, too and increases by 2.7 percent. Even though long-run consumption increases, the overall welfare impact of the reform is negative. This is the case, since the reduction in consumption in the short-run receives a larger weight compared to the increased consumption expenditures in the long-run when computing the welfare implication of the tax reform. ${ }^{41}$

Comparing our results for the 2008 reform with the ones for the reform alternative, one can see that the capital gains tax is the driving force for the slump in the corporate firm's activity following the 2008 reform. The capital gains tax leads to a full double taxation of corporate profits under the 'New View' of dividend taxation, i.e. if investments are financed by retained earnings which make up the lion's share of corporate firm's investment funds in our model. ${ }^{42}$

Under the reform alternative which abstains form the taxation of capital gains our results show a completely different picture. Corporate firms' investments and labour de-

\footnotetext{
${ }^{41}$ ifoMOD is a fully dynamic model and therefore the measure for welfare is computed from the whole phase of transition.

${ }^{42}$ Following the empirical evidence on German corporations' financing behaviour provided by the German Stock Market Institute (DIA 2004) we calibrate the model in a way that 59 percent of all corporate investments are financed by retained earnings, 36 percent by debt and just 5 percent by new equity.
} 
mand increase by 14.4 and 10.2 percent respectively and the output produced by corporate firms grows by 11.5 percent in the long-run. This huge demand for production factors deteriorates the activity of non-corporate firms. Non-corporate firms investments and labour demand drop by 18.1 and 15.5 percent, respectively. Even though non-corporate firms' output declines by 17.5 percent, total output in the economy rises by 1.4 percent.

Despite the growth in overall output, the reform alternative implies a welfare loss as well - even if the decline in welfare is less pronounced under the reform alternative compared to the 2008 reform. Welfare in terms of GDP drops by just 0.3 percent (or by 0.5 percent in terms of household's welfare), while long-run consumption increases by more than eight percent. The negative welfare results are the result of the major reduction in short-run consumption by almost five percent.

Furthermore, financing the reform alternative is more costly in the short-run compared to the 2008 tax reform since there are no tax revenues collected from capital gains taxation. In the short-run, the government budget records a shortfall of about Euro 60 billion compared to just Euro 36 billion under the 2008 tax reform. In the long-run, the increased economic activity leads to higher tax receipts resulting in a budget surplus of about Euro 33 billion. The annuity stream is, however, still negative.

Sensitivity Analysis A comprehensive sensitivity analysis is another major advantage associated with numerical CGE models. So, a numerical CGE model is not only able to determine the quantitatively dominating effect of any reform package per se, but a comprehensive sensitivity analysis provides additional insights into the quantitative impact of each respective policy measure under consideration. In our example of the German corporate tax reform of 2008, the core elements encompass a major reduction of the corporate tax burden, the imposition of a withholding tax on capital gains, and a lowering of preexisting interest stripping possibilities, i.e. the tightening of debt interest deduction rules. In order to isolate the economic impact of each of these three elements, we conduct three separate sensitivity analyses which are presented in Table 8. 
Table 8: Sensitivity Analysis with regard to a 1-\% reduction in the...

\begin{tabular}{|c|c|c|c|c|c|c|}
\hline & \multicolumn{2}{|c|}{ (1) Corporate Tax } & \multicolumn{2}{|c|}{ (2) Capital Gains Tax } & \multicolumn{2}{|c|}{ (3) $I S R^{1)}$} \\
\hline & Total & C-Firms & Total & C-Firms & Total & C-Firms \\
\hline GDP & 0.15 & 0.74 & 0.04 & 0.26 & 0.01 & 0.05 \\
\hline Investments & 0.27 & 0.91 & 0.08 & 0.32 & 0.02 & 0.06 \\
\hline Labour Demand & 0.05 & 0.65 & 0.01 & 0.24 & 0.0 & 0.05 \\
\hline Welfare & \multicolumn{2}{|c|}{0.05} & \multicolumn{2}{|c|}{0.02} & \multicolumn{2}{|c|}{-0.00} \\
\hline Consumption $^{2)}$ (in \%) & \multicolumn{2}{|c|}{$0.00 / 0.21$} & \multicolumn{2}{|c|}{$0.01 / 0.06$} & \multicolumn{2}{|c|}{$-0.00 / 0.01$} \\
\hline Budget Deficit $^{2)}$ (Bil. $\left.€\right)$ & \multicolumn{2}{|c|}{$-2.5 / 0.77$} & \multicolumn{2}{|c|}{$-0.1 / 0.44$} & \multicolumn{2}{|c|}{$0.01 / 0.01$} \\
\hline 1) Interest Stripping Rule; ${ }^{2)}$ sho & ong & changes; & & & & \\
\hline
\end{tabular}

Source: own calculations using ifoMod.

For the first sensitivity analysis we start from the final steady state equilibrium under the 2008 tax reform and reduce the corporate tax burden by one percent from initially 29 to 28.7 percent. This one percent reduction in the corporate tax rate fosters corporate investments by almost one percent such that total investments rise by almost 0.3 percent. Corporate firms' employment increases by 0.65 percent and the respective output by 0.74 percent. In terms of consumption and welfare, we find that the marginal reduction of the corporate tax rate increases long-run consumption by 0.2 percent while welfare rises by 0.05 percent. Financing the reform becomes, however, more expensive, -2.5 percent in the short-run, while long-run tax receipts increase by almost 0.8 percent.

The second sensitivity analysis focuses on a one percent reduction of the capital gains tax. ${ }^{43}$ This change has - similar to the reduction of the corporate tax - a positive effect on macroeconomic variables - however, on a much smaller scale. Total investments rise by 0.08 percent but total output by only 0.04 percent. Labour demand and hence household's consumption is almost unaffected by this variation in the capital gains tax. Nevertheless, the model indicates a positive sign for welfare, even though at a very low level.

The final sensitivity analysis regards the Interest Stripping Rule (IRS). Once again we start form the final steady state prevailing after the 2008 tax reform and lower the share of non-deductible debt interest by one percent, i.e. we increase $z_{3}$ from 0.7 to 0.073 . As Table 8 shows, a marginal increase in the deductibility of debt interest has almost no effect on macroeconomic variables.

\footnotetext{
${ }^{43}$ We reduce the capital gains tax from initially 12.5 to 12.375 percent.
} 


\section{Conclusion}

The use of computable general equilibrium (CGE) models to evaluate policy reforms offers several unique advantages in policy advising. First, a CGE model relies upon pure economic theory and therefore, it delivers the same comparative static result as the underlying theoretical model. In addition, a CGE model quantifies the qualitative effects underlying the theoretical model and thus provides clear-cut predictions of the dominating effect resulting from the policy reform under consideration. ${ }^{44}$ A CGE model, however, not only determines the dominating effect arising from a fundamental reform package but also quantifies all economy-wide repercussions as well as all first and second order effects. Furthermore, dynamic CGE models are a useful instrument to distinguish ex post between short- and long-run effects arising from a policy proposal. These results can then be checked by ways of a sensitivity analysis with regard to their robustness, offering thus a sound foundation for the policy analysis.

This paper introduces the detailed characteristics of ifoMod, a dynamic computable general equilibrium (CGE) model developed to analyse the short- and long-run impact of comprehensive tax reform packages. Besides the model's four building blocks encompassing the firm and household sector, the government and the rest of the world, we additionally explain the main transmission channels at work and analyse the effect of taxes on the behavioural margins of firms and households. The special features of the model are the detailed modelling of the firm sector including corporate and non-corporate firms, an endogenous investment and financial behaviour w.r.t. debt and equity financing, the demand for different skill-types of labour and international portfolio investments. In addition, given the fact that we are also able to simulate not only the final steady state but also the transition path to the new equilibrium, the model can provide additional insights into possible short- and long-run effects of reforms, which might differ to a great extend

\footnotetext{
${ }^{44}$ This feature is especially important when comprehensive reform packages are evaluated. For instance, in analyzing the impact of a fundamental tax reform which implies a simultaneous change in several tax rates, the theoretical analysis is just able to qualify the impact arising from each single tax rate, separately. A CGE model, however, can determine the dominating effect resulting from the overall reform package and thus offers additional insights which just the theoretical analysis can not provide for .
} 
and which can not be represented by means of a static model. Thus, ifoMod represents a dynamic state-of-the-art CGE model which was appreciated by the GCEA (2005) to be the most advanced CGE model available for policy advise in the field of capital income tax reforms.

In addition, the paper exemplifies how a dynamic CGE model can be used to assess the outcomes of a comprehensive tax reform package by simulating the repercussions of the German corporate tax reform of 2008. We find that the 2008 tax reform leads to a slight increase in the corporate and non-corporate firms marginal effective tax rate by 4.2 and 0.8 percent while the cost of capital of the respective firms rise by 2.8 and 0.6 percent. This is the case since the positive effect of the drastic 10 percentage points reduction in the corporate tax rate is counterbalanced by the introduction of a final withholding tax on capital gains of 25 percent and the interest stripping rule which limits the deductibility of debt interest. Non-corporate firms are negatively affected by the introduction of the so-called tax on the rich. Thus, from the shareholder's point of view investments in the corporate sector become less profitable compared to the ones in the non-corporate sector thus explaining the slump in corporate traded-off against a rise in non-corporate activity as shown in the simulation analysis. In total, the increased activity in the non-corporate sector can not, however, compensate for the loss in corporate output such that overall GDP falls by almost two percent in the long-run. In addition we find, that the German corporate tax reform of 2008 has a negative impact on household's welfare.

To check the robustness of our results, we also conduct an additional simulation of a reform alternative and several sensitivity analyses. We learn from the reform alternative, which mirrors the 2008 tax reform but abstracts from the taxation of capital gains, that the negative impact of the 2008 tax reform on corporate firms is mainly to be attributed to the taxation of capital gains. The sensitivity analyses show, that under the current constellation of tax rates, corporate behaviour is more sensitive to an alteration of the corporate tax rate than to a change in the capital gains tax rate, i.e. that the marginal deadweight loss of a one percent increase in the corporate tax exceeds the one of the capital gains tax. Furthermore, we find that a marginal change in the debt interest deductibility provision has hardly any effect on corporate firm behaviour. 
To summarise, the paper demonstrates how a dynamic CGE model can be used when evaluating the economy wide repercussions of a comprehensive tax reform. It shows the various transmission mechanisms through which taxes affect economic behaviour as well as short- and long-term effects, underlying the importance of CGE models for quantifying the first order effects and economy-wide repercussions of a tax reform, which are all essential for policy advising.

\section{Appendix}

\section{A - Portfolio Choice Problem \& Capital Market Equilibrium}

The representative household chooses among four different asset types, business equity, business debt, as well as domestic and foreign government debt, ${ }^{45}$ in order to maximize her average net of tax portfolio return. ${ }^{46}$ The optimal program states

$$
\begin{aligned}
A_{t}^{C, H}=\max _{A^{j, H}}\left\{\sum_{j}^{4}\left(\alpha^{j, H}\right)^{\frac{1}{1+\zeta}}\left[R_{t}^{j, H} A_{t}^{j, H}\right]^{\frac{\zeta}{1+\zeta}}\right\}^{\frac{1+\zeta}{\zeta}} \\
\text { s.t. } \quad A_{t}^{H}=A_{t}^{V, H}+A_{t}^{B, H}+A_{t}^{D H, H}+A_{t}^{D F, H},
\end{aligned}
$$

where $A^{j, k}, j \in\left\{V^{f}, B, D^{k}\right\}, k \in\{H=$ domestic, $F=$ foreign $\}$ denotes the asset type, (equity, $V^{f}$, debt, $B$, or bonds, $D^{k}$,) held by investor $k$. The variable $R^{j, H}=\left(1+r^{j}\right)$ represents the respective net of tax return on asset $A^{j}$. The variable $\alpha^{j, H}$ is a specific taste parameter for each of the four different asset types $j$ and $\zeta$ denotes the elasticity of substitution within the portfolio. ${ }^{47}$ The first order conditions with regard to each asset

\footnotetext{
${ }^{45}$ The gross and net return to each of the four assets are summarised in Table 2.

${ }^{46}$ According to the residence principle of taxation, we assume that there is no withholding tax at source, but all returns are taxed in the country of residence of the asset holder. Morover, in conformity with the empirical evidence on the so-called home bias, (see French and Poterba, 1991) equity capital is non-tradeable and thus only domestically owned. Similarly, domestic households are not allowed to hold foreign equity capital.

${ }^{47}$ This elasticity is assumed to be finite if assets are imperfect substitutes but it becomes infinite if assets are perfect substitutes.
} 
type $A^{j, H}$ is given by

$$
\left(a^{j, H}\right)^{\frac{1}{1+\zeta}}\left(R^{j, H}\right)^{\frac{\zeta}{1+\zeta}}\left(A^{j, H}\right)^{-\frac{1}{1+\zeta}}\left\{\sum_{j}^{4}\left(\alpha^{j, H}\right)^{\frac{1}{1+\zeta}}\left[R^{j, H} A^{j, H}\right]^{\frac{\zeta}{1+\zeta}}\right\}^{\frac{1}{\zeta}}-\lambda=0 .
$$

with $\lambda$ denoting the Lagrangian Multiplier. If we substitute each of the four first order conditions in the constrain (A1.2) the optimal portfolio shares, $A^{j, H}$, can be expressed as a function of optimal unit asset demands

$$
A_{t}^{j, H}=a_{t}^{j, H} A_{t}^{H} \quad \text { with } \quad a_{t}^{j, H}=\alpha^{j, H}\left[\frac{R_{t}^{j, H}}{R_{t}^{c o m p, H}}\right]^{\zeta} .
$$

Using the taste parameters as weights, the after tax return to the composite portfolio, $R^{c o m p, H}$, is defined by the weighted average of the four different rates of return offered by each asset type ${ }^{48}$

$$
R_{t}^{c o m p, H}=\left[\sum{ }_{j}^{4} \alpha^{j, H}\left(R_{t}^{j, H}\right)^{\zeta}\right]^{1 / \zeta}
$$

Capital Market Equilibrium: Domestic and foreign asset markets clear whenever aggregate domestic and foreign demands match the supply of the corresponding asset type. According to eq. (A1.6a), the total amount of domestic business equity is determined by the size of corporate and non-corporate equity, $V^{C}+V^{N}$, which is exclusively in the hands of domestic investors.
(a) Domestic Equity:
$A^{V, H}=A^{V}=V^{C}+V^{N}$,
(b) Business Bonds:$$
A^{B, H}+A^{B, F}=A^{B}=B^{C}+B^{N},
$$
(c) Domestic Gov. Bonds
$A^{D H, H}+A^{D H, F}=A^{D H}=D^{G}$,
(d) Foreign Gov. Bonds
$A^{D F, H}+A^{D F, F}=A^{D F}=D^{F}$.

The aggregate supply of international tradeable domestic business debt is determined via the production side of the domestic economy and amounts to the sum of corporate and non-corporate firm debt, $B^{C}+B^{N}$. A similar interpretation applies to eq. (A1.6c and d), however, the supply of domestic and foreign governmental bonds, $D^{G}$ and $D^{F}$, respectively, are determined by the corresponding fiscal policy of each country.

\footnotetext{
${ }^{48}$ The calibration of the specific taste parameters, $\alpha^{j, H}$, is based on data related to the international asset structure as well as on the returns on the different types of assets accoring to: $\alpha^{j, H}=$ $A^{j, H} /\left(R^{j, H}\right)^{\sigma}\left[\sum_{j}^{4} \frac{A^{j, H}}{\left(R^{j, H}\right)^{\sigma}}\right]^{-1}$.
} 


\section{B - Intertemporal Optimization of Domestic Households}

Total wealth, $T W$, includes financial wealth, $\left(1+\bar{r}^{H}\right) A^{H}$, and human capital, $H$ representing the present value of wages, $H_{t}=\sum_{Z=t}^{\infty}\left\{\sum_{i}^{3}\left[\left(1-\tau^{L, i}\right) w_{i, Z} l_{i, Z}^{S}+\tau^{L, i} L T A_{i, Z}\right]+T_{s}^{H}-(1+\right.$ $\left.\left.\tau_{s}^{C}\right) \sum_{i}^{3} \varphi\left(l_{i, Z}^{S}\right)\right\} \prod_{u=t+1}^{Z} \frac{G}{\left(1+r_{u}\right)}$ with. $i \in\{l, m, h\}$.

The explicit expression for the marginal propensity to consume is

$$
\begin{aligned}
m p c_{t} & =\left(1+\tau_{t}^{C}\right)^{1-\sigma} \cdot\left(m c_{t}\right)^{-1} \\
\text { with } \quad m c_{t} & =\left(1+\tau_{t}^{C}\right)^{1-\sigma}\left\{\sum_{s=t}^{\infty}\left[1+\tau_{s}^{C}\right]^{1-\sigma} \prod_{u=t+1}^{s}\left[\rho^{H, \sigma}\left(\frac{G}{1+\bar{r}_{u}}\right)^{1-\sigma}\right]\right\}^{-1} .
\end{aligned}
$$

In the steady state when all variable grow at the same rate, the expression for the marginal propensity to consume simplifies to $m p c^{S S}=1-\rho^{H}$.

During the phse of transition the expression for the marginal propenbsity to consume becomes $m p c_{t}^{T R}=\left(1+\tau_{t}^{C}\right)^{1-\sigma} \cdot\left[\left(1+\tau_{t}^{C}\right)^{1-\sigma}+\rho^{H, \sigma}\left(\frac{G}{1+\overline{r H}_{t+1}}\right)^{1-\sigma} m c_{t+1}\right]^{-1}$.

\section{C - Rest of the World}

The foreign economy merely serves to complete the model and hence we model the foreign production and foreign household sectors in a rather simple manner.

Foreign Production: The foreign production sector is described by

$$
\begin{array}{ll}
V^{e}\left(K_{t}^{F}\right)= & \max _{L_{t}^{F}, I_{t}^{F}}\left\{\pi_{t}^{F}+\frac{G^{F}}{1+r_{t+1}^{F}} V^{e}\left(K_{t+1}^{F}\right)\right\} \\
\text { s.t. } & G K_{t+1}^{F}=I_{t}^{F}+(1-\delta) K_{t}^{F},
\end{array}
$$

where $V^{e}=\left(1+r_{t+1}^{F}\right) V_{t}$ denotes the end of period firm value and profits are given by: $\pi_{t}^{F}=F\left(K_{t}^{F}, L_{t}^{F}\right)-w_{t}^{F} L_{t}^{F}-I_{t}^{F}$. The foreign firm's optimal labour demand and investment decision follow once again from the firm value maximization. Optimal labour demand is determined by the equality between the marginal product of labour, $F_{L_{t}^{F}}$, and the wage rate, $w_{t}^{F}$, and optimal investments are achieved when the marginal product of capital, $F_{K_{t}^{F}}$, equals the cost of supplying capital, consisting of the interest, $r_{t}^{F}$, plus depreciation $\delta$. 
Foreign Households: Similar to the domestic households, foreign households have to solve an optimal portfolio choice problem as well when they maximize their life-time. The foreign portfolio holding consists also of four different asset types including foreign equity, domestic business debt and domestic and foreign government bonds

$$
A^{F}=A^{V, F}+A^{B, F}+A^{D H, F}+A^{D F, F} .
$$

Since we abstain from any capital gains taxes in the foreign economy, the foreign average portfolio return is the weighted average of the gross returns earned on each asset held by the foreign investor. According to the long-run stationary solution of the Ramsey model this average portfolio return in foreign, $\bar{r}^{F}$, has to equal the foreign household's long-run rate of time preference, $\rho^{F}$.

$$
\bar{r}^{F}=\frac{i^{B H} A^{B, F}+i^{H} A^{D H, F}+i^{F} A^{D F, F}+r^{F} A^{V, F}}{A^{F}}=\rho^{F}
$$

The foreign household earns interest income on financial wealth, $\left(1+\bar{r}^{F}\right) A^{F}$, earns labour income, $w^{F} L^{F}$, and has expenses for consumption, $C^{F}$, and a lump-sum tax, $T^{F} .49$ Thus, the wealth of the representative foreign agent accumulates according to

$$
G A_{t+1}^{F}=\left(1+\bar{r}_{t}^{F}\right) A_{t}^{F}+w_{t}^{F} L_{t}^{F}-C_{t}^{F}-T_{t}^{F}, \quad \text { with } \quad T_{t}^{F}=\left(i^{F}-g\right) D^{F} .
$$

The optimal program which determines the maximal lifetime utility for the foreign households states

$$
U\left(A_{t}^{F}\right)=\max \left\{u\left(C_{t}^{F}\right)+\rho^{F} U\left(A_{t+1}^{F}\right)\right\} \quad \text { s.t. eq.(A1.11), }
$$

and the solution to it yields the optimal intertemporal pattern for consumption, i.e. the Euler Equation

$$
\frac{u^{\prime}\left(C_{t}^{F}\right)}{u^{\prime}\left(C_{t+1}^{F}\right)}=\frac{\rho^{F}\left(1+\bar{r}_{t}^{F}\right)}{G^{F}} .
$$

\section{References}

[1] Armington P. A (1969): "Theory of Demand for Products Distinguished by Place of Production", IMF Staff Papers 27, 488-526.

\footnotetext{
${ }^{49}$ The lump-sum tax levied on foreign households is just sufficient to pay the debt interest emerging form the foreign government bonds, $\left(i^{F}-g\right) D^{F}$.
} 
[2] Arrow K. J. and G. Debreu (1954): "The Existence of an Equilibrium for a Competitive Economy," Econometrica, 22, 265-90.

[3] Auerbach, A.J. (1979): "Wealth Maximization and the Cost of Capital", Quarterly Journal of Economics, 93/3, 433-446.

[4] Auerbach A.J. and Laurence J.K. (1987): Dynamic Fiscal Policy, Cambridge.

[5] Bandholz, H., Flaig, G., and Mayr, J. (2005): "Wachstum und Konjunktur in OECDLändern: Eine langfristige Perspektive", ifo Schnelldienst, 58/4, 28-36.

[6] Bradford, D.F. (1981): "The Incidence and Allocation Effects of a Tax on Corporate Distributions", Journal of Public Economics, 15/1, 1-22.

[7] Carone, G. and A. Salomäki (2001): "Reforms in Tax Benefit Systems in Order to Increase Employment Incentives in the EU", EC Economic Paper No. 160.

[8] Chirinko, R.S., S.M. Fazzari and A.P. Meyer (1999): "How Responsive is Business Capital Formation to Its User Cost? An Exploration with Micro Data", Journal of Public Economics 74, 53-80.

[9] Chirinko, R.S. (2002): "Corporate Taxation, Capital Formation, and the Substitution Elasticity between Labor and Capital," National Tax Journal, 55/2, 339-355.

[10] Cummins J. G., Hassett, K. A. and Hubbard G. R. (1996): "Tax Reform and Investment: A Cross-Country Comparison," Journal of Public Economics 62, 237-273.

[11] Destatis, German Statistical Office (2005): Statistisches Jahrbuch 2005 für die Bundesrepublik Deutschland, Wiesbaden.

[12] DAI, Deutsches Aktieninstitut (2004): DAI-Factbook, Frankfurt am Main.

[13] Dietz, M. and Keuschnigg, C. (2003): Unternehmenssteuerreform II. Quantitative Auswirkungen auf Wachstum und Verteilung, Schriftenreihe: Finanzwirtschaft und Finanzrecht, Bern: Haupt Verlag.

[14] Dietz M. and Keuschnigg, C. (2004) "Corporate Income Tax Reform in Switzerland," Swiss Journal of Economics, 140, 483-519.

[15] Dietz, M. and Keuschnigg, C. (2007): "A Growth Oriented Dual Income Tax", International Tax and Public Finance, 14/2, 191-221.

[16] Fehr H. (1999): Welfare Effects of Dynamic Tax Reforms, Tübingen: Mohr-Siebeck.

[17] Feldstein, M. (2005): "Structural Reform of Social Security", Journal of Economic Perspectives, 19/2, 33-55.

[18] Flaig G. (1988): "Einkommen, Zinssatz und Inflation - Ein Beitrag zur Erklärung von Konsumwachstumsschwankungen". in: Bombach G., Gahlen B., Ott A.E. (Eds.), Geldtheorie und Geldpolitik, Tübingen, 291-314. 
[19] Fossati, A. and Wiegard, W. (2002): Policy Evaluation with General Equilibrium Models, Routledge Applied Economics, London.

[20] French K. R. and Poterba J.M. (1991) "Investor Diversification and International Equity Markets", American Economic Review 81, 222-226.

[21] German Central Bank (1995) "Das Produktionspotential in Deutschland und seine Bestimmungsfaktoren", Monatsbericht 47/8, 41-57.

[22] German Council of Economic Advisors (2005): Jahresgutachten 2005/06, Wiesbaden.

[23] German Council of Economic Advisors, Max-Planck Institute and ZEW (2006): Reform der Einkommens- und Unternehmensbesteuerung durch die Duale Einkommensteuer, Wiesbaden.

[24] German Ministry of Finance (2007a): From the 2000 Tax Reform to the 2008 Corporate Tax Reform, http://www.bundesfinanzministerium.de.

[25] German Ministry of Finance (2007b): Unternehmensteuerreformgesetz 2008, Bundesgesetzblatt Jahrgang 2007 Teil I Nr. 40, http://www.bundesfinanzministerium.de.

[26] Gordon R. H. and Lee Y. (2001) "Do Taxes Affect Corporate Debt Policy? Evidence from US Corporate Tax Return Data," Journal of Public Economics 81, 195-224.

[27] Jorgenson, D. W. and K.-Y. Yun (2001): Lifting the Burden: Tax Reform, The Cost of Capital, and U.S. Economic Growth, Cambridge: MIT Press.

[28] Keuschnigg C. (2004): Eine Steuerreform für mehr Wachstum in der Schweiz, Zürich: Avenir Suisse.

[29] King, M. (1974): "Dividend Behaviour and the Theory of the Firm," Economica, 41/1, $25-34$.

[30] King, M. (1977): "Public Policy and the Corporation," London: Chapman and Hall.

[31] King R.G. and Rebelo S.T. (1990) "Public Policy and Economic Growth: Developing Neoclassical Implications," Journal of Political Economy 98, 127-150.

[32] Maiterth R. und H. Müller (2007): „Unternehmensteuerreform 2008 - Mogelpackung statt großer Wurf", Quarterly Journal of Economic Research, 2/2007, 49-73.

[33] Modigliani, F. and Miller, M. (1958): "The Cost of Capital, Corporation Finance and the Theory of Investment," American Economic Review, 48, 261-297.

[34] OECD, Organisation for Economic Co-operation and Development (1991): Taxing Profits in a Global Economy: Domestic and International Issues, Paris.

[35] Ramsey, F.P. (1928), "A Mathematical Theory of Saving," Economic Journal, 38/152, 543-559. 
[36] Radulescu, D. M. (2007): CGE Models and Capital Income Tax Reforms. The Case of a Dual Income Tax for Germany, Heidelberg: Springer.

[37] Roskamp, K. A. (1977): "Labor Productivity and the Elasticity of Factor Substitution in West German Industries", The Review of Economics and Statistics 59, 366-371.

[38] Scarf, H.E., (1967): "On the computation of equilibrium prices" in Fellner, W.J. (ed.), Ten Economic Studies in the tradition of Irving Fischer, Wiley, New York.

[39] Shoven, J. B. and Whalley, J., (1972) "A General Equilibrium Calculation of the Effects of Differential Taxation of Income from Capital in the U.S.," Journal of Public Economics, 1/3-4, 281-321.

[40] Shoven, J.B. and Whalley, J., (1973) "General Equilibrium with Taxes: A Computational Procedure and an Existence Proof," The Review of Economic Studies, 40/4, 475-89.

[41] Sinn, H.-W. (1991): "Taxation and the Cost of Capital: The 'Old' View, the 'New' View, and Another View", in D. Bradford, ed., Tax Policy and the Economy 5, NBER, 25-54.

[42] Sørensen P. B. (2001) OECDTAX: A Model of Tax Policy in the OECD Economy, Technical Working Paper, University of Copenhagen.

[43] Stimmelmayr, M. (2007): Fundamental Capital Income Tax Reforms: Discussion and Simulation using ifoMOD, Tübingen: Mohr Siebeck.

[44] Summers L.H. (1981): "Tax Policy, the Rate of Return and Savings" National Bureau of Economic Research No. 995.

[45] Tobin J. A (1969): "General Equilibrium Approach to Monetary Theory", Journal of Money, Credit and Banking ; 1; 15-29.

[46] Valkonen T. (1999): The Finnish Corporate and Capital Income Tax Reform: A General Equilibrium Approach, Helsinki: ETLA.

[47] Walras, Léon (1877, printed 1954): Elements of Pure Economics, Harvard University Press.

[48] Whited T. N. (1994): "Problems with identifying adjustment costs from regressions of investment on q," Economic Letters 46, 339-344. 